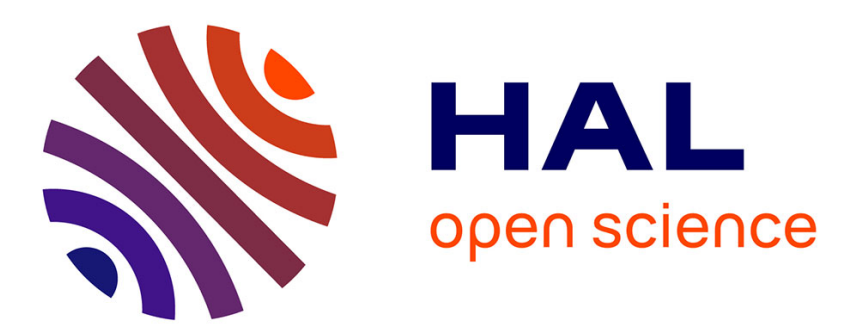

\title{
Use of calculation method for optimization of pulse-arc welding modes using highly alloy welding material
}

\author{
A. V. Zavdoveev, V. D. Poznyakov, O.A. Gaivoronskyi, A. M. Denysenko, T.
} Baudin

\section{- To cite this version:}

A. V. Zavdoveev, V. D. Poznyakov, O.A. Gaivoronskyi, A. M. Denysenko, T. Baudin. Use of calculation method for optimization of pulse-arc welding modes using highly alloy welding material. Automatic Welding, 2021, 2021 (4), pp.10-15. 10.37434/as2021.04.02 . hal-03287120

\section{HAL Id: hal-03287120 \\ https://hal.science/hal-03287120}

Submitted on 15 Jul 2021

HAL is a multi-disciplinary open access archive for the deposit and dissemination of scientific research documents, whether they are published or not. The documents may come from teaching and research institutions in France or abroad, or from public or private research centers.
L'archive ouverte pluridisciplinaire HAL, est destinée au dépôt et à la diffusion de documents scientifiques de niveau recherche, publiés ou non, émanant des établissements d'enseignement et de recherche français ou étrangers, des laboratoires publics ou privés. 
A.V. Zavdoveev, V.D. Poznyakov, O.A. Gaivoronskyi, A.M. Denysenko, T. Baudin

\section{- To cite this version:}

A.V. Zavdoveev, V.D. Poznyakov, O.A. Gaivoronskyi, A.M. Denysenko, T. Baudin. 2021, 2021, pp.10-15. 10.37434/as2021.04.02 . hal-03287120

. Avtomatičeskaâ svarka (Kiev),

\section{HAL Id: hal-03287120}

\section{https://hal.archives-ouvertes.fr/hal-03287120}

Submitted on 15 Jul 2021

HAL is a multi-disciplinary open access archive for the deposit and dissemination of scientific research documents, whether they are published or not. The documents may come from teaching and research institutions in France or abroad, or from public or private research centers.
L'archive ouverte pluridisciplinaire HAL, est destinée au dépôt et à la diffusion de documents scientifiques de niveau recherche, publiés ou non, émanant des établissements d'enseignement et de recherche français ou étrangers, des laboratoires publics ou privés. 


\title{
ОПТИМІЗАЦІЯ ЗА РОЗРАХУНКОВИМ МЕТОДОМ РЕЖИМІВ ІМПУЛЬСНО-ДУГОВОГО ЗВАРЮВАННЯ З ВИКОРИСТАННЯМ ВИСОКОЛЕГОВАНОГО ЗВАРЮВАЛЬНОГО МАТЕРІАЛУ
}

\author{
А.В. Завдовєєв ${ }^{1}$, В.Д. Позняков ${ }^{1}$, О.О. Гайворонський ${ }^{1}$, А.М. Денисенко ${ }^{1}$, Т. Baudin $^{2}$ \\ 'IE3 ім. Є.О. Патона НАН України. 03150, м. Київ, вул. Казимира Малевича, 11. E-mail: office@paton.kiev.ua \\ ${ }^{2}$ Université Paris-Saclay, CNRS, Institut de chimie moléculaire et des ma tériaux d'Orsay, 91405 Orsay, France, thierry. \\ E-mail:baudin@u-psud.fr
}

\begin{abstract}
Використання сучасних технологій імпульсно-дугового зварювання дозволяє суттєво підвищити якість зварних з'єднань. Разом з тим велика кількість можливих режимів зварювання стримують розвиток та впровадження імпульсних технологій у сучасному виробництві. Це пов'язано з тим, що при зварюванні пульсуючою дугою існують як мінімум чотири незалежно змінних параметри, що у сукупності потребує проведення великої кількості експериментів для з'ясування їх впливу. Для оптимізації кількості експериментів у даному дослідженні реалізовано експериментально-розрахунковий алгоритм Тагучі для процесу зварювання пульсуючою дугою з використанням високолегованого зварювального матеріалу. Показано кількісний вклад кожного змінного параметру зварювання у формуванні глибини проплавлення. Запропоновано оптимальні режими зварювання, що забезпечують задану глибину проплавлення. Бібліогр. 15 , табл. 6 , рис. 4.
\end{abstract}

Ключові слова: зварювання пульсуючою дугою, глибина проплавлення, алгоритм Тагучі, високолегований зварювальний матеріал

Імпульсно-дугове зварювання (ІДЗ) якісно відрізняється від традиційного зварювання в захисних газах [1-4]. Це зумовлено розширеними можливостями при ІДЗ впливати на процеси плавлення і переносу електродного металу, на структуроутворення в металі шва та ЗТВ зварного з'єднання, регулювати форму шва, глибину проплавлення тощо. На сьогодні цей спосіб зварювання знаходить все більш широке використання в світовій практиці при виготовленні відповідальних зварних конструкцій з високоміцних сталей [4-7].

На даний час провідними компаніями розроблено багато інверторних джерел зварювального струму, що побудовані на імпульсних технологіях для MIG/MAG зварювання. Так, шведська фірма «Esab» розробила джерело живлення «Aristo 500», американська фірма Hobart - «Ultra-Arc 350», німецька фірма EWM - Phoenix 501 pulse. Спектр завдань, які можуть вирішуватися при ІДЗ, роблять їх затребуваними у вітчизняному виробництві відповідальних металоконструкцій. Але слід зазначити, що ці джерела мають вбудовані програми з великим спектром режимів, $з$ яких вибрати оптимальний для конкретного варіанту зварювання досить важко.

При ІДЗ існує чотири змінних параметри режиму - базовий струм $(I b)$, струм імпульсу $(I P)$, частота $(f)$ і шпаруватість $(C)$. Тому при виборі режиму необхідно провести велику кількість експериментів. Відомо також, що існує експериментально-розрахунковий метод Тагучі [8], який дозволяє оцінити влив кожного окремо 3 параметрів режиму на формування зварного з'єднання.

Метою даної роботи було провести вибір режимів ІДЗ із застосуванням методу Тагучі, що забезпечують задану глибину проплавлення V-подібної розробки без зазору стикового з'єднання високоміцної легованої сталі із зворотнім формуванням шва при застосуванні високолегованого зварювального матеріалу.

Методика експерименту. При виконанні досліджень було обрано параметри ІДЗ пульсуючою дугою, які наведено в табл. 1.

У зазначеному експерименті є чотири незалежно керованих параметра процесу і три експери-

Таблиця 1. Обрані параметри при ІДЗ

\begin{tabular}{|c|c|c|c|c|c|c|c|}
\hline \multirow{3}{*}{ Параметр } & \multirow{3}{*}{ Примітка } & \multicolumn{6}{|c|}{ Рівень } \\
\hline & & \multicolumn{3}{|c|}{ Значення } & \multicolumn{3}{|c|}{ Кодування } \\
\hline & & Мінімальне & Середнє & Максимальне & Мінімальне & Середнє & Максимальне \\
\hline Струм імпульсу, А & A & 160 & 200 & 240 & 1 & 2 & 3 \\
\hline Струм паузи, А & $\mathrm{B}$ & 80 & 120 & 140 & 1 & 2 & 3 \\
\hline Частота, Гц & $\mathrm{C}$ & 0,5 & 1 & 5 & 1 & 2 & 3 \\
\hline Шпаруватість, \% & $\mathrm{D}$ & 40 & 60 & 80 & 1 & 2 & 3 \\
\hline
\end{tabular}

Завдовєєв А.В. - https://orcid.org/0000-0003-2811-0765, Позняков В.Д. - https://orcid.org/0000-0001-8581-3526, Гайворонський О.О. - https://orcid.org/0000-0002-5922-5541, Baudin T. - https://orcid.org/0000-0002-6765-360X А.В. Завдовєєв, В.Д. Позняков, О.О. Гайворонський, А.М. Денисенко, Т. Baudin 
ментальних рівня. Повною мірою для чотирьох факторів і трьох рівнів треба було б провести $3^{4}=81$ експеримент. Метод, запропонований Тагучі, використовує ортогональні масиви (OAs), щоб визначити в реальному часі мінімальну кількість експериментів для оцінки усіх факторів проектування. У такій експериментальній схемі кожен фактор оцінюється індивідуально і один не впливає на інший. Умови, що виникли в цьому дослідженні, тобто чотири параметра разом з їх трьома рівнями, підходять для вибору L9 матриці в якості експериментального проекту. У табл. 2 представлено дев'ять експериментальних випробувань в реальному часі, які складені за схемою L9 $\left(3^{4}\right)$ відповідно до методу Тагучі $[8,9]$. При цьому експерименти необхідно проводити в випадкових порядках з метою обходу джерел шуму.

Розрахунок співвідношення сигнал/шум. При проведенні експериментів використовуються різні параметри процесу, що дають різні значення «відгуку». У якості «відгуку» обрано глибину проплавлення (ГП). В ході експериментальних випробувань необхідно було оцінити вплив кожного обраного фактора за допомогою отриманих «відгуків», які можуть бути не унікальними і мати як бажані, так і небажані характеристики. За методом Тягучі співвідношення сигнал/шум $(S / N)$ є відхиленням якісної характеристики від бажаного значення. Серед трьох доступних робочих значень - більш високе, більш низьке і номінальне (HB, LB i NB) - слід обирати під час розрахунку співвідношення $S / N$.

Розрахунок співвідношення $S / N$ виконували відповідно рівняння (1). Узагальнені розраховані співвідношення $S / N$ для всіх експериментів представлено в табл. 3.

$$
\frac{S}{N}=-10 \log \left(\frac{\sum_{1}^{n} \frac{1}{Y^{2}}}{n}\right) .
$$

Наступним кроком в аналізі є поділ впливу кожного окремого параметра на всі три розглянутих рівня і ранжування їх в порядку їх впливу до параметру відгуку. Це можливо тому, що обрана схема експерименту вкладається в ортогональну матрицю L9 [10].

Середня ефективність фактора розраховується шляхом ділення суми результатів випробувань, що включають фактор, на кількість випробувань, проведених на тому ж рівні (рівняння (2)):

$$
\text { наприклад, }<S / N>_{A 1}=\left(S / N_{1}+S / N_{2}+S / N_{3}\right) / 3 \text {. }
$$

Внесок окремих факторів на глибину проплавлення. Номінальний контроль остаточної відповіді вимагає знання ступеня вкладу окремих параметрів процесу, і їх можна оцінити за допомогою статистичного методу, а саме ANOVA [11]. У ме- тодології ANOVA $S S, S S^{\varsigma}, D, V$ і $P$ є типовими символами параметрів, що використовуються в наведеному вище аналізі для подання факторів, суми і скоригованої суми квадратів, ступеня свободи, дисперсії і процентного вкладу кожного фактора відповідно [12, 13]. Коротке пояснення перерахованих вище факторів представлено нижче.

Загальна сума квадратів $S S_{T}$ може бути розрахована з відносини $S / N$ з рівняння (3), в якому використовуються терміни «загальна кількість експериментів $(m=9) »$ та «i-е поточне співвідношення сигнал/шум пі:

$$
S S_{T}=\sum_{i=1}^{9} S / N_{i}^{2}-\frac{1}{9}\left(\sum_{i=1}^{9} S / N_{i}\right)^{2} .
$$

Сума квадратів факторів, позначених як $S S_{p}$, розраховується за рівнянням (4), яке має наступні умови: фактор «р», номер його рівня як «j», повторення кожного рівня для перевіреного фактора $p$, як ' $t$ ' (=3), підсумовування співвідношення сигнал/шум $(S / N)$, що зв'язує цей коефіцієнт $p$ і його рівень $j$ як $S / N \mathrm{pj}=\left(S / N_{1}+S / N_{2}+S / N_{3}\right)$ для рівня $A_{j}=1,\left(S / N_{2}+S / N_{3}+S / N_{4}\right)$ для рівня $A_{j}=2,\left(S / N_{7}+\right.$ $\left.+S / N_{8}+S / N_{9}\right)$ для рівня $A_{j}=3$

$$
S S_{P}=\sum_{j=1}^{3} \frac{\left(\sum S / N p j\right)^{2}}{3}-\frac{1}{9}\left(\sum_{i=1}^{9} S / N_{i}\right)^{2} .
$$

Ступінь свободи (DOF) є одним з елементів, який слід враховувати при розрахунку ANOVA [11]. $D_{p}$ та $V_{p}$ - позначення, що використовуються для представлення ступеня свободи і дисперсії фактора $p$. $V_{p}$ визначається у відсотках з використанням $S S_{p}$ по $D_{p}$ відповідно до рівняння (5).

$$
V_{p}(\%)=\frac{S S_{p}}{D_{p}} \cdot 100 .
$$

Підсумовування DOF, супроводжуване поруч випробувань і середнього значення, називається загальним DOF. Ступінь свободи для середнього значення завжди дорівнює 1. Отже, загальна ступінь свободи для цього експериментального дослідження дорівнює 8, що дорівнює кількості випробувань (9 випробувань) -1, а ступінь свободи для параметрів дорівнює 2, що виходить шляхом вирахування 1 з числа рівнів параметрів (3 рівня).

Різниця між $S S_{p}$ (сумою квадратів факторів) і твором дисперсії помилок та DOF кожного тестового фактора називається скоригованої сумою квадратів і позначається як $S S_{P}^{\prime}$, який розраховується за рівнянням (6).

$$
S S_{P}^{\prime}=S S_{P}-D_{P} V_{e} .
$$

Процентне співвідношення протестованих факторів між їх виправленою сумою та загальною сумою квадратів називається їх відсотковим внеском 
і позначається як $P_{p}$. Рівняння (7) використовується для визначення $P_{p}$ :

$$
P_{p}(\%)=\frac{S S_{P}^{\prime}}{S S_{T}} \cdot 100 .
$$

Результати та обговорення. Макрошліфи наплавлень, виконаних у відповідності до програми (табл. 2) наведені на рис. 1, де номер відповідає режиму наплавлення. Результати розрахунку глибини проплавлення для зазначених зразків наведено у табл. 3 .

3 використанням алгоритму Тагучі, враховуючі відповідні значення співвідношення сигнал/шум, розраховано середні значення для кожного рівня та параметру зварювання, які наведено у табл. 4 .
Як видно з розрахунків, струм імпульсу для параметра глибини проплавлення ранжується за номером «1», що вказує його найбільший вплив на глибину проплавлення, ніж струм паузи, частота та шпаруватість.

Результати ANOVA дають інформацію про кількісний вклад кожного параметра.

Тест на відповідність для перевірки повторюваності. Після вибору оптимального рівня параметрів процесу проектування, це обов'язковий крок для визначення і перевірки поліпшення характеристик якості з використанням оптимального рівня параметрів проектування. Згідно [11-15], прогнозоване ставлення сигнал/шум для опти-

Таблиця 2. Виконання випробувань на основі проектного плану

\begin{tabular}{|c|c|c|c|c|c|c|c|c|}
\hline \multirow{2}{*}{ Номер } & \multicolumn{2}{|c|}{ Струм імпульсу, А } & \multicolumn{2}{|c|}{ Струм паузи, А } & \multicolumn{2}{|c|}{ Частота, Гц } & \multicolumn{2}{|c|}{ Шпаруватість, \% } \\
\hline & Величина & Код & Величина & Код & Величина & Код & Величина & Код \\
\hline 1 & 160 & 1 & 80 & 1 & 0,5 & 1 & 40 & 1 \\
\hline 2 & 160 & 1 & 120 & 2 & 1 & 2 & 60 & 2 \\
\hline 3 & 160 & 1 & 140 & 3 & 5 & 3 & 80 & 3 \\
\hline 4 & 200 & 2 & 80 & 1 & 1 & 2 & 80 & 3 \\
\hline 5 & 200 & 2 & 120 & 2 & 5 & 3 & 40 & 1 \\
\hline 6 & 200 & 2 & 140 & 3 & 0,5 & 1 & 60 & 2 \\
\hline 7 & 240 & 3 & 80 & 1 & 5 & 3 & 60 & 2 \\
\hline 8 & 240 & 3 & 120 & 2 & 0,5 & 1 & 80 & 3 \\
\hline 9 & 240 & 3 & 140 & 3 & 1 & 2 & 40 & 1 \\
\hline
\end{tabular}
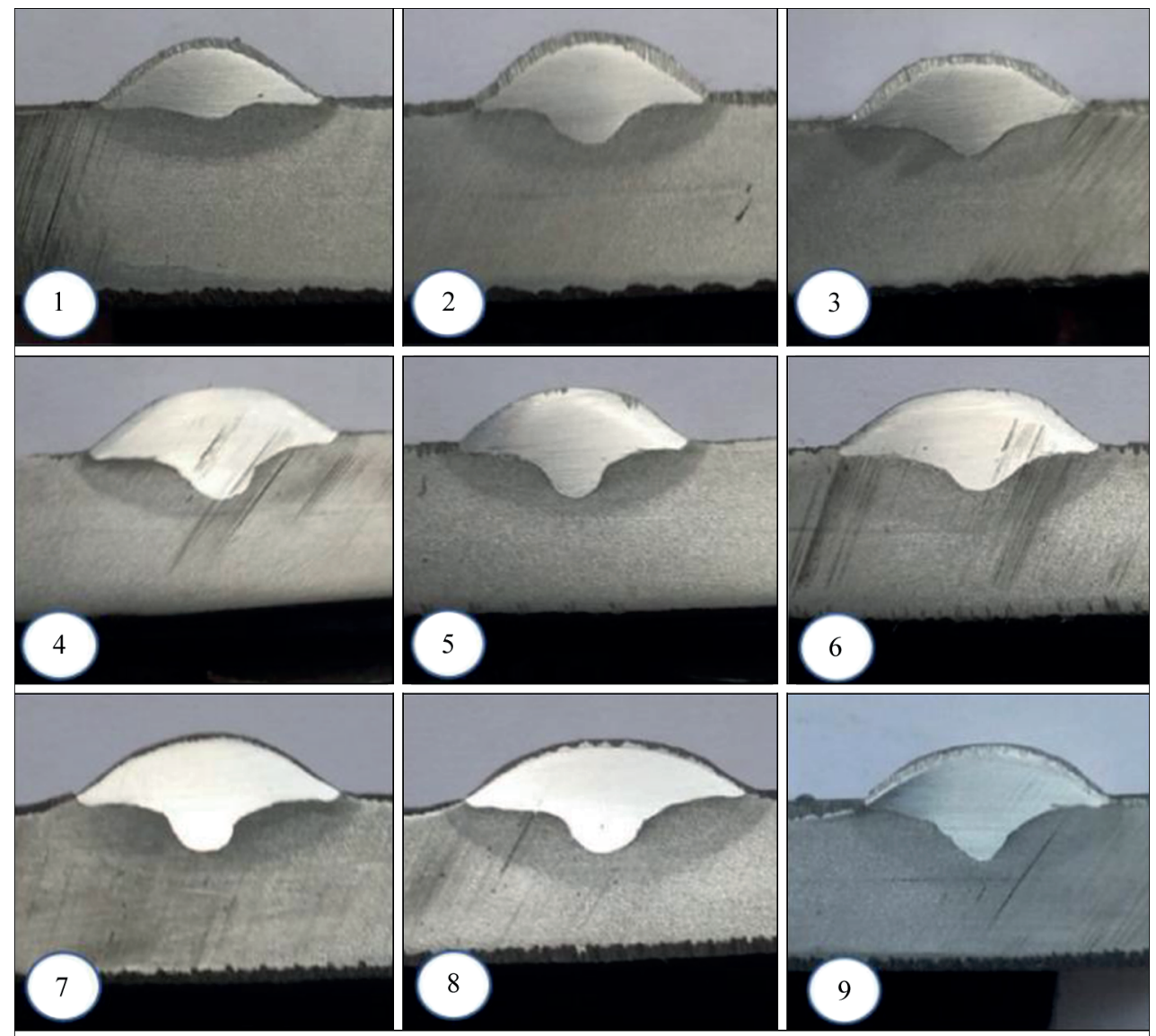

10 мм

Рис. 1. Фото макрошліфів експериментальних наплавлень 
Таблиця 3. Результати вимірювання глибини проплавлення та співвідношення сигнал/шум

\begin{tabular}{|c|c|c|c|c|c|c|c|}
\hline \multirow{2}{*}{$\begin{array}{l}\text { Номер } \\
\Pi / \Pi\end{array}$} & \multicolumn{4}{|c|}{ Параметри } & \multicolumn{2}{|c|}{ Відгук } & \multirow[b]{2}{*}{$Q / V$ кДж/мм } \\
\hline & $\begin{array}{c}\text { Струм імпульсу, } \\
\text { А }\end{array}$ & $\begin{array}{c}\text { Струм паузи, } \\
\text { A }\end{array}$ & $\begin{array}{c}\text { Частота, } \\
\text { Гц }\end{array}$ & Шпаруватість, \% & ГП & $S / N$ & \\
\hline 1 & 160 & 80 & 0,5 & 40 & 0,88 & $-1,128$ & 0,42 \\
\hline 2 & 160 & 120 & 1 & 60 & 2,159 & 6,673 & 0,55 \\
\hline 3 & 160 & 140 & 5 & 80 & 2,47 & 7,851 & 0,61 \\
\hline 4 & 200 & 80 & 1 & 80 & 3,37 & 10,55 & 0,68 \\
\hline 5 & 200 & 120 & 5 & 40 & 3,31 & 10,4 & 0,62 \\
\hline 6 & 200 & 140 & 0,5 & 60 & 2,091 & 6,374 & 0,72 \\
\hline 7 & 240 & 80 & 5 & 60 & 2,926 & 9,322 & 0,67 \\
\hline 8 & 240 & 120 & 0,5 & 80 & 3,597 & 11,12 & 0,93 \\
\hline 9 & 240 & 140 & 1 & 40 & 3,349 & 10,5 & 0,75 \\
\hline
\end{tabular}

Таблиця 4. Розрахунок значень $S / N$ за алгоритмом Тагучі

\begin{tabular}{|c|c|c|c|c|c|c|}
\hline Параметр & Примітка & Рівень 1 & Рівень 2 & Рівень 3 & $\Delta=\operatorname{max-\operatorname {min}}$ & Ранг \\
\hline Струм імпульсу, А & $\mathrm{A}$ & 4,465 & 9,107 & 10,31 & 5,85 & 1 \\
\hline Струм паузи, А & $\mathrm{B}$ & 6,249 & 9,395 & 8,241 & 3,15 & 4 \\
\hline Частота, Гц & $\mathrm{C}$ & 5,454 & 9,24 & 9,189 & 3,79 & 2 \\
\hline Шпаруватість, $\%$ & $\mathrm{D}$ & 6,588 & 7,456 & 9,84 & 3,25 & 3 \\
\hline
\end{tabular}

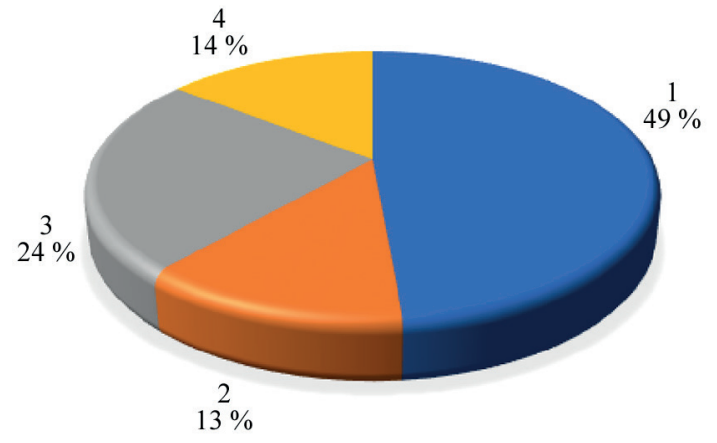

Рис. 2. Результати обчислень за методом ANOVA: 1 - струм імпульсу; 2 - струм паузи; 3 - частота; 4 - шпаруватість

Таблиця 5. Результати оцінки прогнозованого числа та підтвердження результатів для оптимального стану процесу PA-GMAW (ГП максимальна)

\begin{tabular}{|c|c|c|c|c|c|c|}
\hline \multirow{2}{*}{ Параметри } & \multirow{2}{*}{ A } & \multirow{2}{*}{ B } & \multirow{2}{*}{$\mathrm{C}$} & \multirow{2}{*}{$\mathrm{D}$} & \multicolumn{2}{|r|}{$S / N$} \\
\hline & & & & & Прогноз & Експеримент \\
\hline $\begin{array}{c}\text { Оптимальне } \\
\text { кодоване } \\
\text { значення }\end{array}$ & 3 & 2 & 2 & 3 & \multirow[t]{2}{*}{14,9} & \multirow[t]{2}{*}{12,04} \\
\hline $\begin{array}{c}\text { Оптимальне } \\
\text { значення }\end{array}$ & 240 & 120 & 1 & 80 & & \\
\hline \multicolumn{7}{|c|}{ Відхилення = 19 \% } \\
\hline
\end{tabular}

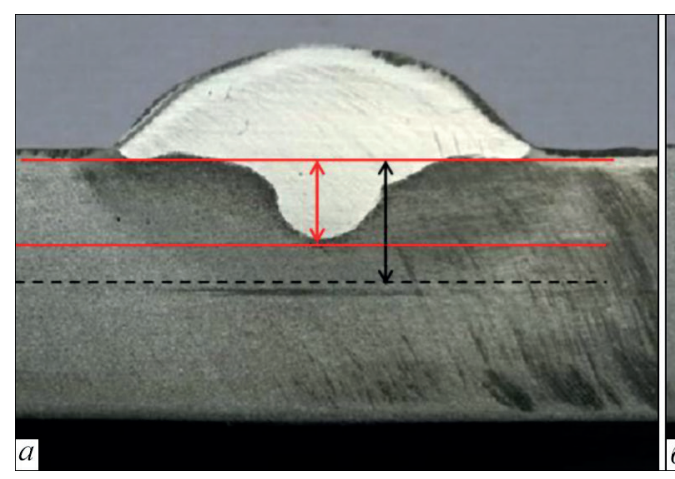

Рис. 3. Макрошліфи наплавлень, виконаних згідно розрахованим режимам, з максимальною (a) та мінімальною (б) ГП (пун-

ктирна лінія - розрахункова величина проплавлення, суцільна - експериментальна) може бути обчислене як

$$
\hat{\eta}=\eta_{m}+\sum_{i=1}^{n}\left(\bar{\eta}_{i}-\eta_{m}\right) .
$$

У наведеному вище рівнянні $\eta_{m}, \eta_{i}$ i $n$ представляють середнє співвідношення $S / N$ (табл. 4) і загальне число важливих проектів експериментальних параметрів, що впливають на якість. Прогнозоване співвідношення $S / N$ може бути знайдено 3 використанням оптимальних параметрів процесу зварювання пульсуючою дугою (табл. 5, 6).

Результати перевірки прогнозованих режимів зварювання 3 метою отримання максимальної та

Таблиця 6. Результати оцінки прогнозованого числа та підтвердження результатів для оптимального стану процесу PA-GMAW (ГП мінімальна)

\begin{tabular}{|c|c|c|c|c|c|c|}
\hline Параметри & $\mathrm{A}$ & $\mathrm{B}$ & $\mathrm{C}$ & $\mathrm{D}$ & \multicolumn{2}{|c|}{$S / N$} \\
\cline { 1 - 4 } $\begin{array}{c}\text { Оптимальне } \\
\text { кодоване } \\
\text { значення }\end{array}$ & 2 & 1 & 2 & 1 & Прогноз & Експеримент \\
\hline $\begin{array}{c}\text { Оптимальне } \\
\text { значення }\end{array}$ & 200 & 80 & 1 & 40 & $-1,13$ & $-1,21$ \\
\hline
\end{tabular}

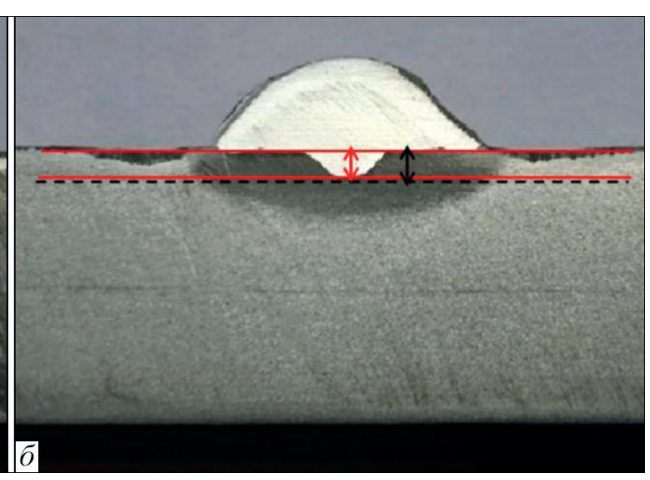

мального рівня параметрів процесу проектування 


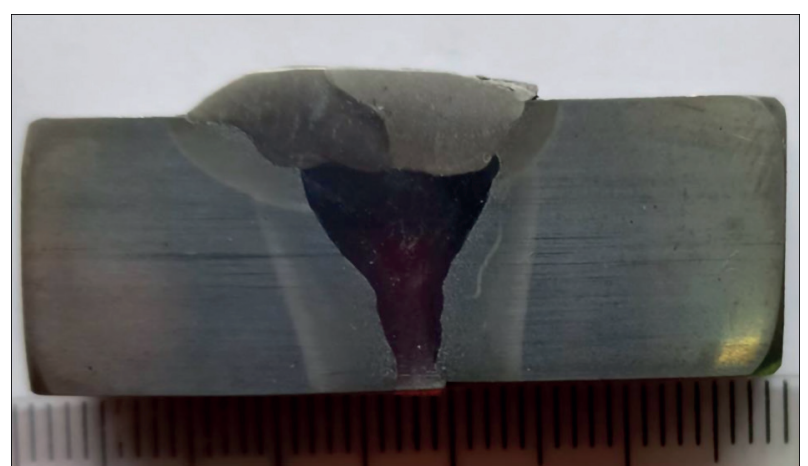

Рис. 4. Стикове з'єднання високоміцної сталі (V-подібне, без зазору, притуплення 4 мм)

мінімальної глибини проплавлення при зварюванні пульсуючою дугою наведено на рис. 3. Як видно, експериментально-разрахунковий алгоритм Тагучі дає можливість 3 високою точністю прогнозувати відгук досліджуваного параметра, а саме глибини проплавлення.

Результати досліджень були використані при виборі оптимального режиму ІДЗ кореневого шару V-подібного з'єднання високоміцної сталі, розробка якого була виконана без зазору і мала притуплення 4 мм (рис. 4). При цьому отримати належну якість зварного з'єднання, а саме забезпечити проплавлення кореня розробки із зворотним формуванням шва вдалося при виконанні вже першого експерименту.

Слід зазначити, що метод Тагучі може також використовуватися при виборі режимів ІДЗ багатошарових з'єднань з метою отримання оптимальних розмірів ЗТВ. Це $\epsilon$ дуже важливим чинником, який суттєво впливає на технологічні та експлуатаційні властивості зварних з'єднань відповідальних металоконструкцій з високоміцних легованих термічно зміцнених сталей. Дослідження в цьому напрямку виконуються, результати будуть представлені в наступних публікаціях.

\section{Висновки}

1. Проведено дослідження впливу режимів імпульсно-дугового зварювання (струм зварювання, струм паузи, частота, шпаруватість) на глибину проплавлення при застосуванні високолегованого зварювального дроту при застосуванні експериментально-розрахункового методу Тагучі. Показана можливість керування параметрами зварювання пульсуючою дугою 3 метою отримання необхідної глибини проплавлення у широкому діапазоні.

2. Встановлено, що переважний вплив на глибину проплавлення має струм імпульсу. Далі за вагомістю впливу йдуть частота, шпаруватість та струм паузи. Кількісний аналіз дозволив встановити, що вплив перелічених параметрів розподіляється наступним чином: струм імпульсу
- $49 \%$, струм паузи - $13 \%$, частота - $24 \%$, шпаруватість $-14 \%$.

3. Проведені дослідження дозволили запропонувати оптимальні режими імпульсно-дугового зварювання, що забезпечують задані величини глибини проплавлення, а саме мінімальну та максимальну. Верифікаційний експеримент показав, що у рамках незначних відхилень прогнозовані значення глибини проплавлення корелюють 3 експериментальними.

4. Експериментально-розрахунковий метод Тагучі $є$ потужним та перспективним інструментом, що може застосовуватися при виборі оптимальних режимів і розробці технологій імпульсно-дугового зварювання.

\section{Список літератури/References}

1. Poznyakov, V.D., Zavdoveev, A.V., Gajvoronsky, et al. (2018) Effect of pulsed-arc welding modes on the change of weld metal and haz parameters of welded joints produced with Sv-08kh20N9G7T wire. The Paton Welding J., 9, 7-12. DOI: https://doi.org/10.15407/tpwj2018.09.02

2. Palani, P.K., Murugan, N. (2006) Selection of parameters of pulsed current gas metal arc welding. $J$. of Materials Processing Technology 172, 1-10.

3. Tong, H., Ueyama, T. (2001) Quality and productivity improvement in aluminium alloy thin sheet welding using alternating current pulsed metal inert gas welding system. Sci. Technol. Weld. Join., 6 (4), 203-208.

4. Rajasekaran, S. (1999) Weld bead characteristics in pulsed GMA welding of Al-Mg alloys. Weld. J., 78(12), 397-407.

5. Zavdoveev, A., Rogante, M., Poznyakov, V. et al. (2020) Development of the PC-GMAW welding technology for TMCP steel in accordance with welding thermal cycle, welding technique, structure and properties of welded joints. Reports in Mechanical Engineering, 1, 1, 26-33.

6. Murray, P.E. (2002) Selecting parameters for GMAW using dimensional analysis. Weld. J., 81(7), 125-131.

7. Essers, W.G., Van Gompal. (1984) Arc control with pulsed GMA welding. Ibid, 64 (6), 26-32.

8. Ross, P.J. (1988) Taguchi techniques for quality engineering: loss function, orthogonal experiments, parameter and tolerance design. New York, McGraw-Hill, 1988 Aug.

9. Phadke, M.S. (1995) Quality engineering using robust design. Prentice Hall PTR, 1995 Dec 1.

10. Ma, Y, Hu, H, Northwood, D, Nie, X. (2007) Optimization of the electrolytic plasma oxidation processes for corrosion protection of magnesium alloy AM50 using the Taguchi method. J. Mater. Process. Technol., Feb 2, 182, 58-64.

11. Wang, Y, Northwood, DO. (2008) Optimization of the polypyrrole-coating parameters for proton exchange membrane fuel cell bipolar plates using the Taguchi method. J. Power Sources, Oct 15, 185(1), 226-32.

12. Magudeeswaran, G, Balasubramanian, V, Reddy, GM. (2008) Effect of welding processes and consumables on high cycle fatigue life of high strength, quenched and tempered steel joints. Materials \& Design., Oct 1, 29(9), 1821-7.

13. Yousefieh, M, Shamanian, M, Saatchi, A. (2011) Optimization of the pulsed current gas tungsten arc welding (PCGTAW) parameters for corrosion resistance of super duplex stainless steel (UNS S32760) welds using the Taguchi method. $J$. Alloys Compd., Jan 21, 509(3), 782-8.

14. Do Kim, K, Han, DN, Kim, HT. (2004) Optimization of experimental conditions based on the Taguchi robust design for the formation of nano-sized silver particles by chemical reduction method. Chem Eng J., Nov 15, 104, 55-61.

15. Yang WP, Tarng YS. (1998) Design optimization of cutting parameters for turning operations based on the Taguchi method. J. Mater. Process. Technol., Dec 1, 84, 122-129. 
Надійшла до редакції 24.02.2021

Для переводчиков

TAGUCHI OPTIMIZATION BY MODE PULSED ARC WELDING FOR PROVIDING A FIXED ROOT LAYER DEPTH OF PENETRATION WELDED CONNECTION WHEN USING HIGH WELDING MATERIAL

A.V. Zavdoveev ${ }^{1}$, VD Poznyakov ${ }^{1}$, OO Gaivoronsky $^{1}$, A.M. Denisenko ${ }^{1}$, T. Baudin ${ }^{2}$

${ }^{1}$ IEZ them. C.O. Paton of the National Academy of Sciences of Ukraine. 03150, Kyiv, street Kazimir Malevich, 11. E-mail: office@paton.kiev.ua

${ }^{2}$ Université Paris-Saclay, CNRS, Institut de molecular chemistry et des ma teríaux d'Orsay, 91405 Orsay, France, thierry.baudin@u-psud.fr

The use of modern pulse-arc welding technologies can significantly improve the quality of welded joints. However, a large number of possible welding modes constrain the development and implementation of pulse technology in modern production. This is due to the fact that there are at least four independently variable parameters in pulsed arc welding, which together require a large number of experiments to determine the effect of these parameters. To optimize the number of experiments, this study implemented the experimental calculation algorithm Taguchi for the process of welding with a pulsating arc (PA-GMAW) using high-alloy welding material. The quantitative contribution of each variable welding parameter in the formation of the penetration depth is shown. Optimal welding modes providing a given penetration depth are proposed. Ref. 15, tabl. 5, fig. 4.

Keywords: puls arc welding, penetration depth, Taguchi algorithm, high-alloy welding material

Reference

1. Poznyakov, V.D., Zavdoveev, A.V., Gajvoronsky, A.A., Denisenko, A.M. ??? (2018) Effect of pulsed-arc welding modes on the change of weld metal and haz parameters of welded joints produced with Sv-08kh20N9G7T wire. The Paton Welding J., 9, 7-12.

2. Palani, P.K., Murugan, N. (2006) Selection of parameters of pulsed current gas metal arc welding. Journal of Materials Processing Technology 172, $1-10$.

3. Tong, H., Ueyama, T. (2001) Quality and productivity improvement in aluminium alloy thin sheet welding using alternating current pulsed metal inert gas welding system. Sci. Technol. Weld. Join., 6 (4), 203-208.

4. Rajasekaran, S. (1999) Weld bead characteristics in pulsed GMA welding of $\mathrm{Al}-\mathrm{Mg}$ alloys. Weld. J., 78(12), 397-407.

5. Zavdoveev, A., Rogante, M., Poznyakov, V. et al. (2020) Development of the PC-GMAW welding technology for TMCP steel in accordance with welding thermal cycle, welding technique, structure and properties of welded joints. Reports in Mechanical Engineering, 1, 1, 26-33.

6. Murray, P.E. (2002) Selecting parameters for GMAW using dimensional analysis. Weld. J., 81(7), 125-131.

7. Essers, W.G., Van Gompal. (1984) Arc control with pulsed GMA welding. Ibid, 64 (6), 26-32.

8. Ross, PJ. (1988) Taguchi techniques for quality engineering: loss function, orthogonal experiments, parameter and tolerance design. New York, McGrawHill, 1988 Aug.

9. Phadke, MS. (1995) Quality engineering using robust design. Prentice Hall PTR, 1995 Dec 1.

10. Ma, Y, Hu, H, Northwood, D, Nie, X. (2007) Optimization of the electrolytic plasma oxidation processes for corrosion protection of magnesium alloy AM50 using the Taguchi method. J. Mater. Process. Technol., Feb 2, 182(1-3), 58-64.

11. Wang, Y, Northwood, DO. (2008) Optimization of the polypyrrole-coating parameters for proton exchange membrane fuel cell bipolar plates using the Taguchi method. J. Power Sources, Oct 15, 185(1), 226-32.

12. Magudeeswaran, G, Balasubramanian, V, Reddy, GM. (2008) Effect of welding processes and consumables on high cycle fatigue life of high strength, quenched and tempered steel joints. Materials \& Design., Oct 1, 29(9), 1821-7.

13. Yousefieh, M, Shamanian, M, Saatchi, A. (2011) Optimization of the pulsed current gas tungsten arc welding (PCGTAW) parameters for corrosion resistance of super duplex stainless steel (UNS S32760) welds using the Taguchi method. J. Alloys Compd., Jan 21, 509(3), 782-8.

14. Do Kim, K, Han, DN, Kim, HT. (2004) Optimization of experimental conditions based on the Taguchi robust design for the formation of nano-sized silver particles by chemical reduction method. Chem Eng J., Nov 15, 104(1-3), 55-61.

15. Yang, WP, Tarng, YS. (1998) Design optimization of cutting parameters for turning operations based on the Taguchi method. J. Mater. Process. Technol., Dec 1, 84(1-3), 122-9. 